\title{
The Impact of Demographic Changes on the Organization of Emergency Medical Services: the Case of Slovenia
}

\author{
Tatjana Kitić Jaklič ${ }^{1}$, Jure Kovač
}

\author{
${ }^{1}$ General Medical Practice Activities of the Gorenjska Region, Kranj, \\ Community Health Centre, Gosposvetska ulica 10, 4000 Kranj, Slovenia \\ tkitic@gmail.com
} ${ }^{2}$ University of Maribor, Faculty of Organizational Sciences, Kidričeva cesta 55a, 4000 Kranj, Slovenia
jure.kovac@fov.uni-mb.si

\begin{abstract}
Background and Purpose: The modern environment requires that organizations (profit and non-profit) continually harmonize their organizational models with changes in their respective environments and with their own visions and strategies for further development. The organizational structure of Emergency Medical Services (hereinafter EMS) is currently a very topical issue in Slovenia, given that a project to establish a new organization of EMS is currently underway at the national level. By examining the case of one region in Slovenia, this article presents an analysis of factors that impact on the number and types of EMS activities and depicts a forecast of future trends for the requirement of EMS. The analysis presents the initial phase of a strategic planning process for the mentioned activity and consequently, a starting point for the formation of an organizational EMS model.

Methodology: This article presents an analysis of factors that impact on the formulation of an EMS model on the basis of research carried out for one geographical region of Slovenia. For the previous period, data was collected from 2002 to 2014. The software tool used for the analysis was STATA 13.0. For the purpose of forecasting a five-year period trend we used statistical package RStudio and Hyndman's Forecast package given that this package contains algorithms for forecasting univariate time series including exponential smoothing using automated spatial models and ARIMA modelling.

Results: The research has confirmed a correlation between social/environmental factors and the rate of increase in the demand for EMS. A population's age structure has been identified as the key social factor that increases the need for EMS. On the basis of this finding, this article presents a model for forecasting growth trends in the scope of EMS activities.

Conclusion: The research study has identified some important elements that are imperative to take into consideration when formulating an EMS network at the prehospital level. Population ageing has emerged as a key social factor. In the accordance with forecasted trends, an increase in the burden placed on EMS activities may also be anticipated in the future.
\end{abstract}

\section{Keywords: strategic planning, foresight, trends, emergency medical services (EMS), organizational model}

\section{Introduction}

Healthcare systems across the world face major challenges, with all developed countries being subject to a list of unfavourable external trends that include demographic changes, incredibly rapid technological development, rising user demand for healthcare services and rising health-related costs in the context of the global financial crisis (Walshe and Smith, 2011, pg. 3). In addition to these factors, a number of trends that reflect the socio-economic situation in our society should also be highlighted. These include globalization, which has a decisive impact on the 
international migration of populations in different parts of the world, global financial and geopolitical upheavals, various crisis situations due both to natural disasters as well as various political and other social conflicts, urbanization and environmental degradation (Rodriguez-Garcia, 2001; Ramani et al., 2008, pp. 16 - 18; Bufon, 2014, pp. 9 - 32).

The above described problems and challenges faced by healthcare institutions are therefore not new. Since the 1980s, there has taken place an intensive debate on the issue of how to increase the efficiency of various public enterprises and other non-profit organizations in a rapidly changing environment. The primary goal of providers as well as others involved in the healthcare system is to improve the services that are on offer to patients. The most important value is understood to be a positive treatment outcome, which we also strive to achieve through the provision of financial sustainability.

Solutions to improve the efficiency of healthcare institutions began being sought in management theories and management best practices of for-profit organizations. Due to an increase in the efficiency and quality of service provision, the introduction of modern management methods has become a necessity (Kowalczyk, 2002; Berwick et al., 2008; Hedegaard and Ahl, 2012; Kuhlmann and von Knorring, 2014).

An integral component of healthcare includes emergency medical services (hereinafter 'EMS'). This is a public service that performs medical treatment for suddenly sick or injured individuals and is an integral component of the public healthcare network at the primary (prehospital) and secondary levels of health care. Over the past twenty years, researchers from most developed countries report on coming to terms with trends that reflect an increase in the number of EMS treatments performed, particularly as a consequence of negative demographic trends, epidemiological and social changes (Fischer et al., 2000; Cabrera et al., 2011). From this perspective, it is therefore necessary to understand current trends towards the reorganization of the EMS system, which we are also witness to in our environment. The modern and carefully constructed EMS system, particularly at the primary level, is without doubt a condition for better treatment outcomes and lower healthcare costs in the continuing care provided by all other levels of the healthcare system.

This paper focuses on an analysis of the impact of social factors in the number and type of required EMS treatments by examining the case of one Slovenian region, which also represents the starting phase for the strategic planning of an EMS organizational model. The analysis was carried out for the Gorenjska region in such a way as to further enable the transfer of the model to the national level.

The aim of the research is to formulate a proposal for the creation of an EMS organizational model that will enable the efficient use of human and other resources and that will also enable the achievement of efficient and effective health care from the perspective of the health care industry, health care providers and patients. The primary goal of this research is to predict trends for the next five-year period with the help of extrapolation methods and to determine the impact of demographic population changes as regards the provision of EMS activities.

\section{Theoretical Background}

\subsection{Strategic Planning in Healthcare}

The greatest problem faced by managers today is that they must be able to foresee the future development of their own organization within the complex environment in which it operates and on the basis of understanding specific trends and the development of related factors. In the framework of strategic management (or strategic planning), various instruments, methods, techniques and approaches for managing an increasingly more complex environment have recently been developed (Varkey and Bennet, 2010; Rodríguez Perera and Peiró, 2012). The purpose of strategic planning is to encourage organizations towards strategic thinking, working and learning (Bryson, 2004, pg. 27).

A strategic approach places an emphasis on analysis over own resources and trends within the environment. On the basis of this mutual analysis, long-term directions for the successful development of an organization are shaped by a strategic approach (Hitt et al., 2009; Robbins and Coulter, 2009; Daft, 2010; Bleicher, 2011).

The process of strategic planning is made up of several interrelated steps or phases (Bryson, 2004; Varkey and Bennet, 2010; Rodríguez Perera and Peiró, 2012). According to Bryson, the process of strategic planning can be demonstrated more clearly and comprehensively by the following ten steps (Bryson, 2004, pp. 32-34): Step 1 - Initiate and agree on a strategic planning process, Step 2 - Identify organizational mandates, Step 3 - Clarify organizational mission and values, Step 4 - Assess the external and internal environments to identify strengths, weaknesses, opportunities and threats, Step 5 - Identify strategic issues faced by the organization, Step 6 - Formulate strategies to manage the issues, Step $7-$ Review and adopt the strategies or strategic plan, Step 8 - Establish an effective organizational vision, Step 9 - Develop an effective implementation process, Step 10 - Reassess strategies and the strategic planning process. Because these steps do not necessarily or exclusively follow linearly, it is more correct to speak of "a cycle of strategic changes". Within this framework, a plan is used for all public and non-profit organizations and may also be used for the institution as a whole, as well as for its individual components.

Because a depiction of the analysis of social/environmental factors in the number and type of EMS treatments 
is the main purpose of this article, we shall focus exclusively on the fourth step of this cycle. The greatest value of this step lies in obtaining information that is of central meaning for the survival and growth of the organization. This step provides insight into the organization as a whole in relation to its internal/external environment, which should prevent its vulnerability in relation to any potential subsequent negative effects that may emerge from its surroundings. Fundamentally, this step is about obtaining information on the strengths and weaknesses of organizations, which may easily be related to the opportunities and challenges faced by an organization (Bryson, 2004, pg. 124). Identifying opportunities and challenges enables the shaping of a vision and perceptions of the organization in future.

According to Bryson, the influence of the external environment may be divided into three different categories: (i) influence on forces and trends, (ii) key resource controllers and (iii) influence of competitive and collaborative forces (Bryson, 2004, pg. 32). Among all environmental factors that influence on the strategic planning of the development of EMS, those identified as key factors include demographic trends as well as some socio-economic and geographical characteristics of the external environment (Rodriguez-Garcia, 2001; Matter-Walstra et al, 2006; Guidelines on EMS, 2008; Bufon, 2014, pg. 266; Verdel, 2015, pgs. 21 - 22).

\subsection{Organization of Emergency Medical Services in the Gorenjska Region}

At the primary level of healthcare service provision, EMS is organized in such a way as to ensure its continuous operation during a time of emergency services, as well as during regular clinical activities or as a special unit in accordance with the criteria and grid set forth in the EMS Guidelines (Official Gazette RS, no. 106/2008). In shaping the network of units of prehospital EMS, a series of professionally justified criteria needs to be taken into consideration so that under normal circumstances accessibility to EMS is enabled for most inhabitants in the shortest possible time or within acceptable time limits. In so doing, the following criteria must be taken into account: the number of inhabitants; the proportion of persons aged over 65; geographical conditions and territorial distance; level of threat due to accidents, traffic and similar; development of transportation links; distance to hospitals; response team for carrying out EMS; frequency of events within a particular area (Official Gazette RS, no. 106/2008).

Other factors also impact on the provision of a wider range of EMS services. Tourism, for example, plays a role due to numerous factors that include: an increase in the number of people (tourists) in a given tourist destination, a higher risk for the onset of various injuries that may result from intense performance of sports and other activities during holiday seasons, the possibility of more rapid transmission of infectious disease (Rodriguez-Garcia, 2001; Matter-Walstra et al, 2006). A number of enterprises may be connected with a higher degree of risk in terms of the probability of the onset of work injury, depending on the type of activity performed. This also applies to agriculture. The literature defines acceptable access time as achieving 90 percent access time within 9 minutes or intervention with the highest degree of urgency within 8 minutes in 75 percent of the time (Wu and Hwang, 2009; O'Keeffe et al., 2011). The Regulation on EMS in Slovenia, a new proposal which was submitted for public discussion in April of this year (the debate was closed one month later) has defined as a still acceptable access time for calls with the highest level or urgency as being 10 minutes in urban areas and 20 minutes in rural areas, where the access time must be reached 80 percent of the time in all emergency interventions.

In accordance with the still valid Regulation on EMS, which regulates the conditions, organization and methods of EMS in the Republic of Slovenia, EMS is comprised of doctors and other health workers who are trained in carrying out EMS. At the pre-hospital stage, teams are divided into units $\mathrm{A}$ and $\mathrm{A} 2$, unit $\mathrm{B}$, unit $\mathrm{B}$-ok, unit $\mathrm{C}$ and PHE (prehospital unit). The composition of EMS teams is actually not the only factor for which teams of these services vary, but the scope of their work is also different so that the consequence is variability in the population's access of the population to EMS across different regions of Slovenia.

Our research study was carried out for the Gorenjska region. In Gorenjska region, which is one of Slovenia's 12 regions, the General Medical Practice Services of Gorenjska (hereinafter OZG) is responsible for providing EMS for the entire region. This is an institution that carries out health care at the primary level and implements it via the following organizational units (hereinafter $\mathrm{OE}$ ): $\mathrm{OE}$ Health Care Centre (hereinafter ZD) Kranj, OE ZD Škofja Loka, OE ZD Tržič, OE ZD Radovljica, OE ZD Jesenice, OE ZD Bled and OE ZD Bohinj.

Table 1 provides data that was obtained in the scope of this research pertaining to socio-geographic and other indicators for units within the Gorenjska region.

As evident from the table, growth trends are evident in the Gorenjska region in terms of: the number of inhabitants, population density and the proportion of individuals over the age of 65 . The number of overnight tourist stays and the number of companies located in the region is also on the rise. A downward trend is apparent in the number of traffic accidents. In terms of agriculture, there is an evident reduction in the surface area of usable agricultural land. 
Table 1: Data displayed on socio-geographic and other indicators for Gorenjska region (Source: Statistical Office of the Republic of Slovenia, own review). Demographic information is inclusive of 31 December of the current year for the years 2004 to 2008 and 1 July of the current year for the years 2009 to 2012. The number of enterprises includes company activities listed in group C - K from years 2004 to 2007, while after 2008, all enterprises - registered legal or natural persons that displayed revenue during the years of observation or employed person or persons who work and carry out as their main activity one of the activities listed under the Standard Classification System.

\begin{tabular}{|c|c|c|c|c|c|c|c|}
\hline$\frac{\sim}{\stackrel{\sim}{\sim}}$ & $\frac{\stackrel{?}{g}}{\stackrel{+}{c}}$ & $\begin{array}{l}n \\
\tilde{n}\end{array}$ & $\vec{I}$ & $\overbrace{0}^{\infty}$ & $\underset{\bar{m}}{\bar{\nabla}}$ & $\begin{array}{l}n \\
0 \\
0 \\
0 \\
0\end{array}$ & $\frac{N}{\pi}$ \\
\hline $\overrightarrow{\vec{D}}$ & 官 & $\stackrel{n}{a}$ & $\tilde{\sigma}$ & $\begin{array}{l}\bar{\infty} \\
\infty\end{array}$ & $\underset{\bar{g}}{\bar{\exists}}$ & 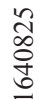 & $\begin{array}{l}\tilde{n} \\
\hat{\sigma}\end{array}$ \\
\hline$\stackrel{\circ}{\stackrel{\circ}{\circ}}$ & $\frac{\tilde{\sigma}}{\tilde{\sigma}}$ & $\vec{n}$ & $\stackrel{0}{0}$ & $\underset{\infty}{\stackrel{\infty}{\sigma}}$ & $\underset{m}{\bar{y}}$ & $\begin{array}{l}n \\
2 \\
\infty \\
\infty \\
2 \\
n\end{array}$ & $\begin{array}{l}n \\
6 \\
6\end{array}$ \\
\hline ஓे & 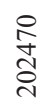 & & $\stackrel{0}{0}$ & 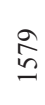 & $\underset{N}{\stackrel{N}{m}}$ & $\begin{array}{l}0 \\
\hat{0} \\
\hat{N} \\
n\end{array}$ & $\begin{array}{l}\stackrel{0}{n} \\
\stackrel{n}{n}\end{array}$ \\
\hline 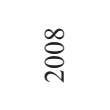 & 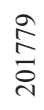 & $\stackrel{+}{\dot{\sigma}}$ & $\underset{\sigma}{*}$ & $\stackrel{8}{I}$ & 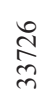 & $\begin{array}{l}\text { すั } \\
\stackrel{\Xi}{\Xi} \\
\Xi\end{array}$ & $\begin{array}{l}\bar{n} \\
\stackrel{y}{ \pm}\end{array}$ \\
\hline ڤ્̀े & 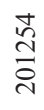 & $\stackrel{\text { Y }}{\dot{\sigma}}$ & గై & $\underset{\sim}{\stackrel{\Delta}{d}}$ & 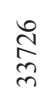 & $\begin{array}{l}\text { ลे } \\
\text { ลे } \\
\text { ป }\end{array}$ & శ్ \\
\hline §ั̊ & 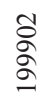 & $\tilde{n}$ & $\ddot{n}$ & ڤ్̊․ & $\stackrel{n}{n}$ & $\begin{array}{l}\underset{\sim}{ \pm} \\
\underset{\sim}{\sim}\end{array}$ & $\begin{array}{l}n \\
\vdots \\
0 \\
0\end{array}$ \\
\hline ¿̊̊ & $\begin{array}{l}n \\
2 \\
2 \\
2 \\
2\end{array}$ & ๙ָ & $\begin{array}{l}n \\
n\end{array}$ & $\stackrel{\circ}{\stackrel{二}{\sim}}$ & 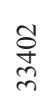 & \begin{tabular}{l}
$\stackrel{0}{\hat{~}}$ \\
\multirow{\delta}{0}{}
\end{tabular} & $\stackrel{\infty}{\infty}$ \\
\hline \multirow[t]{2}{*}{ ঠి } & 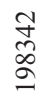 & $\stackrel{\circ}{\sigma}$ & $\stackrel{n}{n}$ & $\frac{m}{\sqrt{N}}$ & $\begin{array}{l}\text { Oे } \\
\text { Wे } \\
\text { mे }\end{array}$ & $\begin{array}{l}\hat{n} \\
\infty \\
\infty \\
\dot{0}\end{array}$ & $\stackrel{\infty}{0}$ \\
\hline & 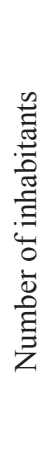 & 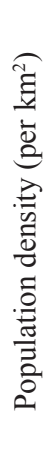 & 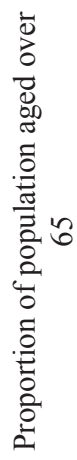 & 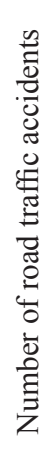 & 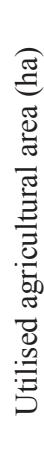 & 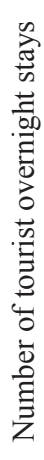 & 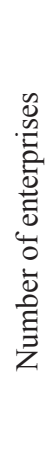 \\
\hline 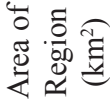 & $\frac{\hat{n}}{\sim}$ & & & & & & \\
\hline $\begin{array}{l}\text {.0 } \\
.00 \\
\stackrel{0}{0}\end{array}$ & 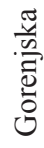 & & & & & & \\
\hline
\end{tabular}




\section{Methodology and Research Model}

The basic aim of this research is to formulate a proposal for the creation of an EMS organizational model. In so doing, the goal of the study is to verify the prevalence of changing trends and to determine the impact of demographic changes on the number and types of EMS activities. Empirical verification is carried out at the regional level for the Gorenjska region.

\subsection{Research Model}

Two research questions have been formulated in accordance with the aim and goal of this research. These are listed following the explanations below.

It is possible to trace the growth of EMS treatments over the past ten years, the intensification of the complexity of cases and therefore, a subjectively greater burden on EMS teams (Močnik, 2012, pg. 1). For the period from 1996 to 2006, the United States reported on an increase of EMS visits by 32 percent, while the number of EMS visits in Spain grew by 23.2 percent between 2001 and 2007 (Cabrera et al., 2011). Prehospital unit Ljubljana has also reported on the increase in the number of EMS treatments in the Ljubljana region. In 2010, 35617 outpatient examinations were performed in this unit along with 3235 emergency interventions and 1731 home visits. In 2013, 36198 outpatient examinations were conducted, along with 2915 emergency interventions and 2700 home visits (Verdel, 2015, number pg. 12).

The purpose of forecasting trends is to be able to identify changing trends in the environment on the basis of quantitative and qualitative research methods in a timely manner so as to form a basis for making further decisions (Müller and Müller-Stewens, 2009). The extrapolation of these trends is one of the basic methods of an organization's strategic planning activities (Capon, 2008, p. 31; Lünger and Luhan, 2010, p. 69). This article displays an analysis and forecasting trends in the number and type of EMS treatments for the next five-year period. The five-year period has been covered because the timeframe for strategic planning requires the most common planning horizon. It was the intent of this research to verify changing trends in the number and types of cases in EMS activities for the region of Gorenjska, so that the following research question has been formulated:

"What is the trend in the number and types of EMS activities in the Gorenjska region?"

Slovenia ranks among those European countries that will be most affected by the consequences of population ageing (Ministry of Health, 2013). A number of countries have reported on a growth trend of healthcare treatments that are the result of population ageing (Salvi et al., 2007; Caley and Sidhu, 2010; Horibata and Takemura, 2015). Because older inhabitants more often become ill due to various chronic diseases, they are more frequent users of healthcare services (Verdel, 2015, pp. 21 - 22). In their study, Šelb-Šemerl and colleagues (2004) have also confirmed that with growth in the proportion of older inhabitants, the burden on the health system will also rise.

It has become apparent that demographic changes are among the most important factors that should be considered in this research study. It was the intention of the researchers to review changing trends in this field and at the same time, to determine the relationship between the proportion of older inhabitants in the region covered by individual EMS units and the number of individual cases covered by EMS. This suggests that the proportion of home visits implemented in areas with a higher proportion of elderly populations is higher due to elderly individuals being more frequently physically impaired. On the basis of this premise, a second research question has been formulated:

"As the most significant demographic factor, how does population ageing impact on the number and types of services carried out by EMS?"

\subsection{Methodology}

The analysis was carried out for the observed region, that is, the Gorenjska region.

Demographic data and information about other socio-geographical indicators was primarily drawn from publications and documents available on the internet pages of the Statistical Office of the Republic of Slovenia. Demographic data is inclusive of data covered on 31 December for each individual year for the period from 2004 to 2008 and on 1 July for each individual year in period from 2009 to 2012.

Data on the proportion of those aged over 65 was also accessible. Because some ZD cover a region with a greater number of municipalities, such as for example ZD Kranj, ZD Škofja Loka, ZD Bled and ZD Jesenice, this analysis was selected for the average value of the proportion of elderly populations in these municipalities, in recognition of the restriction that municipalities are not comparable to each other in size. The analysis covered only complete data, therefore data from the years 2004 to 2012.

In collecting information on the number of EMS treatments, we focused on the following factors: (i) outpatient examinations, (ii) home visits and (iii) emergency interventions on the field. Data was included for the past time period, specifically from the years 2002 to 2014 . For the Gorenjska region, this information was in large part forwarded by service providers. The Ministry of Health forwarded information on the number of emergency interventions conducted in Slovenia, but only for the period from 2008 to 2013. Missing data was forwarded by the National Institute for Public Health.

In searching for the answer to the second research 
question, the independent variable in the analysis was represented by the share of the population over the age of 65 . Dependent variables included the number of outpatient examinations, the number of home visits and the number of emergency interventions.

Information was arranged in Microsoft Office Excel. Because this represents an analysis of panel information that is a combination of temporal and cross-sectional species, STATA 13.0 software was used. A representation of data in graphic form was first conducted, as enabled by STATA. An analysis in the form of a decision algorithm subsequently followed. On the basis of the Hausman test, it was determined which form of the panel regression analysis was more adequate for clarification of this case, with selection being made between the fixed effects and the random effects models.

For the purpose of forecasting a five-year period, statistical package RStudio and Hyndman's Forecast package were used. This enables part automated forecasting that ranks individually required parameters for prediction on the basis of a time series analysis (Hyndman, 2015). Forecast contains algorithms that are used to forecast univariate time series, including exponential smoothing with the assistance of spatial models and automated ARIMA modelling. If the described mechanism did not provide adequate results, a linear extrapolation model was used, where the trend represented an independent variable in the model. Theoretical bases for the execution of statistical analyses were taken from two sources, namely from a book authored by Kohler and Kreuter and another authored by Hyndman (Kohler and Kreuter, 2009; Hyndman, 2015).

\section{Research Results}

Due to space limitations and the restrictions of black and white print, complete analyses are with rare exception not displayed in graphical form, but are instead displayed in tables, in greater detail. This is shown only in individual (major) stages of statistical analysis, as due to space restrictions, it is not possible to display the results for all.

Data on the number of EMS treatments for individual OZG organizational units are more clearly presented in Table 2. Due to space constraints, data for ZD Bohinj and ZD Radovljica are not listed in the table nor is data for the entire analysed time period. In the analysis of trends as regards the number and types of cases, data for these two units (ZD Bohinj and ZD Radovljica) have been graphically depicted together, alongside data for all other units. This is depicted in Figure 1. From Table 2, it is possible to determine that the number of cases is predominantly rising in terms of emergency interventions, home visits and outpatient examinations. This does not apply to only a few rare cases.

It must also be clarified that EMS providers carry out secondary treatments at clinics (for example, peer reviews and coroner services), but these treatments represent a small proportion of all treatments. In addition, due to their being defined by various other legal foundations and also because they are not financially covered by the Health Insurance Institute of Slovenia (hereinafter, ZZZS), they have not been included in this analysis.

\subsection{Predicting Trend Shifts for EMS Treat- ments in Gorenjska Region for the Next 5 Years}

On the basis of time-series data on the number of EMS treatments, a forecast for the Gorenjska region for a particular type of treatment for the next five-year time period was carried out. The forecast trend has been graphically displayed using a linear chart, as shown in Figure 1.

\subsection{Impact of Proportion of Older Inhabi- tants on the Number and Type of EMS Activities}

Particularly unfavourable demographic statistics are apparent in the municipalities of Kranjska Gora (which is under the competence of OE ZD Jesenice), Bohinj and Bled, given that these are areas with the highest ageing index in the region (the ageing index reveals the number of inhabitants aged 65 and over, per 100 inhabitants aged under 15). The trend displaying the proportion of populations aged over 65 is shown in Figure 2.

The analysis was first used to verify what proportion of EMS treatments are represented by individual EMS treatments, where the time period is between 2008 and 2013. The results of the analysis are displayed in Table 3 .

The analysis has confirmed that the proportion of home visits in regions with a higher proportion of those aged over 65 is greater.Analysis on the basis of a determining test algorithm indicates that a fixed effects model provides sufficient interpretation for the purpose of clarifying the correlation with an independent variable (being the proportion of population aged over 65) using a regression analysis to check the second research question. The Hausman test, which was used to verify whether the remainder was correlated with an independent variable in the model has indicated that the value is $\mathrm{p}<0.05$ in all cases. The fixed effects model controls temporally invariable differences among areas.

This method is designed to measure time invariable causes of the dependent variable (being the number of emergency interventions, the number of home visits and the number of outpatient examinations), which may in this case be used to monitor the causes of observed changes within an individually observed area. This method assumes that some characteristics of an individual unit affects the dependent variable (that is the number of home visits in 
Table 2: Display of data on the number of emergency interventions on the field, home visits and outpatient examinations per healthcare centre in OZG (own review; *-no information).

\begin{tabular}{|c|c|c|c|c|c|c|c|}
\hline 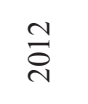 & 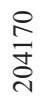 & $\begin{array}{l}n \\
\tilde{n}\end{array}$ & $\vec{I}$ & 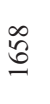 & $\underset{\vec{J}}{\vec{\Xi}}$ & 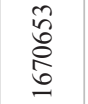 & $\frac{\sim}{n}$ \\
\hline $\overrightarrow{\bar{\partial}}$ & 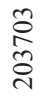 & $\begin{array}{l}n \\
n\end{array}$ & $\tilde{\sigma}$ & $\underset{\infty}{\infty}$ & $\underset{m}{\vec{J}}$ & 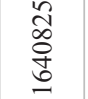 & $\begin{array}{l}\tilde{n} \\
\tilde{\sigma}\end{array}$ \\
\hline$\stackrel{\circ}{\stackrel{\circ}{\sim}}$ & $\frac{\widetilde{\sigma}}{\stackrel{\overbrace{}}{~}}$ & $\vec{n}$ & $\begin{array}{l}\dot{\varphi} \\
\stackrel{0}{0}\end{array}$ & $\underset{\infty}{\stackrel{\infty}{=~}}$ & $\underset{m}{\stackrel{\Xi}{\Xi}}$ & $\begin{array}{l}\curvearrowleft \\
\infty \\
\infty \\
\infty \\
\end{array}$ & $\begin{array}{l}\sqrt[6]{6} \\
6\end{array}$ \\
\hline ஓे & 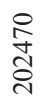 & F & $\begin{array}{l}\ddot{0} \\
\ddot{\bullet}\end{array}$ & î & 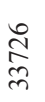 & 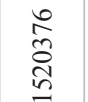 & $\begin{array}{l}\stackrel{0}{n} \\
n \\
n\end{array}$ \\
\hline$\stackrel{\infty}{\stackrel{\infty}{\circ}}$ & 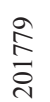 & $\begin{array}{l}\stackrel{+}{*} \\
\stackrel{+}{ }\end{array}$ & $\stackrel{ナ}{\circ}$ & $\stackrel{8}{\beth}$ & 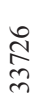 & $\begin{array}{l}\underset{む}{\Xi} \\
\stackrel{\Xi}{\exists}\end{array}$ & $\begin{array}{l}\bar{n} \\
\stackrel{n}{g}\end{array}$ \\
\hline હ্ণ & 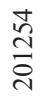 & $\stackrel{\text { İ }}{\dot{H}}$ & $\underset{ٍ}{\tilde{\sigma}}$ & 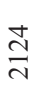 & 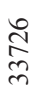 & $\begin{array}{l}\text { ลे } \\
\text { જે } \\
\text { f }\end{array}$ & ชิ \\
\hline ঠి & $\begin{array}{l}\text { ठ̀ } \\
\text { ลे }\end{array}$ & ñ & $\stackrel{\vec{\imath}}{\underline{n}}$ & ஃे & $\stackrel{n}{n}$ & $\begin{array}{l}\stackrel{+}{\sim} \\
\underset{\sim}{\sim}\end{array}$ & \begin{tabular}{l}
$\mathfrak{2}$ \\
\multirow{2}{*}{}
\end{tabular} \\
\hline ¿̊) & $\begin{array}{l}\cong \\
\infty \\
2 \\
2\end{array}$ & ்ָ & $\begin{array}{l}n \\
\ddot{n}\end{array}$ & $\stackrel{\ominus}{\stackrel{二}{\sim}}$ & 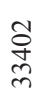 & 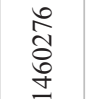 & $\stackrel{\infty}{\curvearrowright}$ \\
\hline \multirow[t]{2}{*}{ ষ্ণ } & 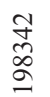 & $\stackrel{\circ}{\circ}$ & $\stackrel{\sim}{\check{n}}$ & $\stackrel{m}{\stackrel{n}{\sim}}$ & 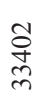 & 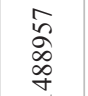 & $\stackrel{\infty}{0}$ \\
\hline & 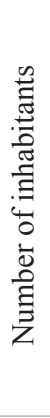 & 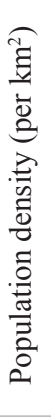 & 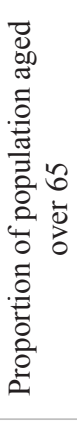 & 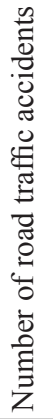 & 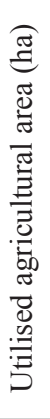 & 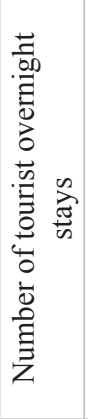 & 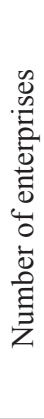 \\
\hline 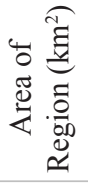 & $\stackrel{\hat{n}}{\vec{\sim}}$ & & & & & & \\
\hline 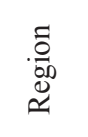 & 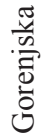 & & & & & & \\
\hline
\end{tabular}




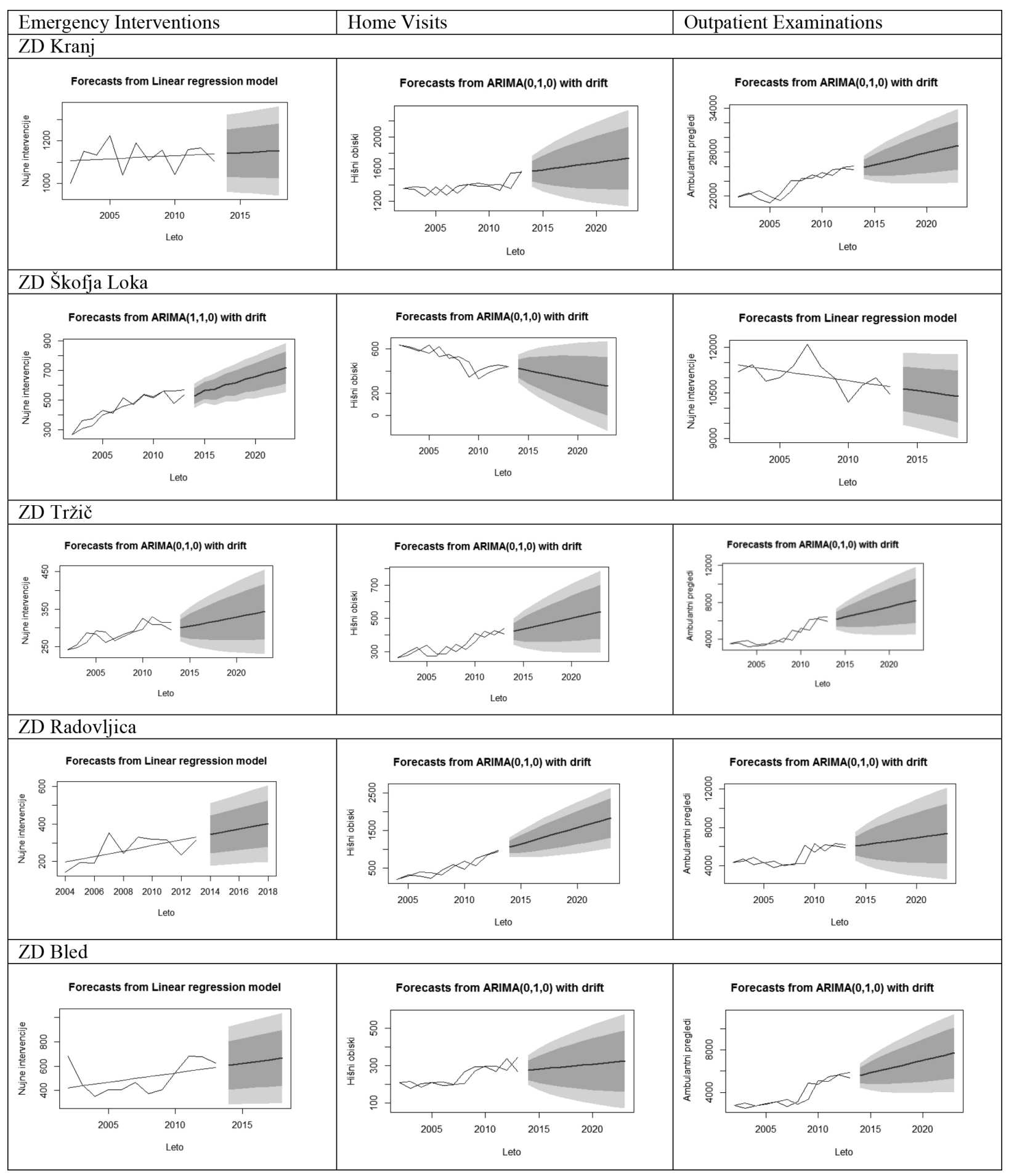

Figure 1: A graphical display of a forecast trend for a number of EMS treatments in the Gorenjska region. 


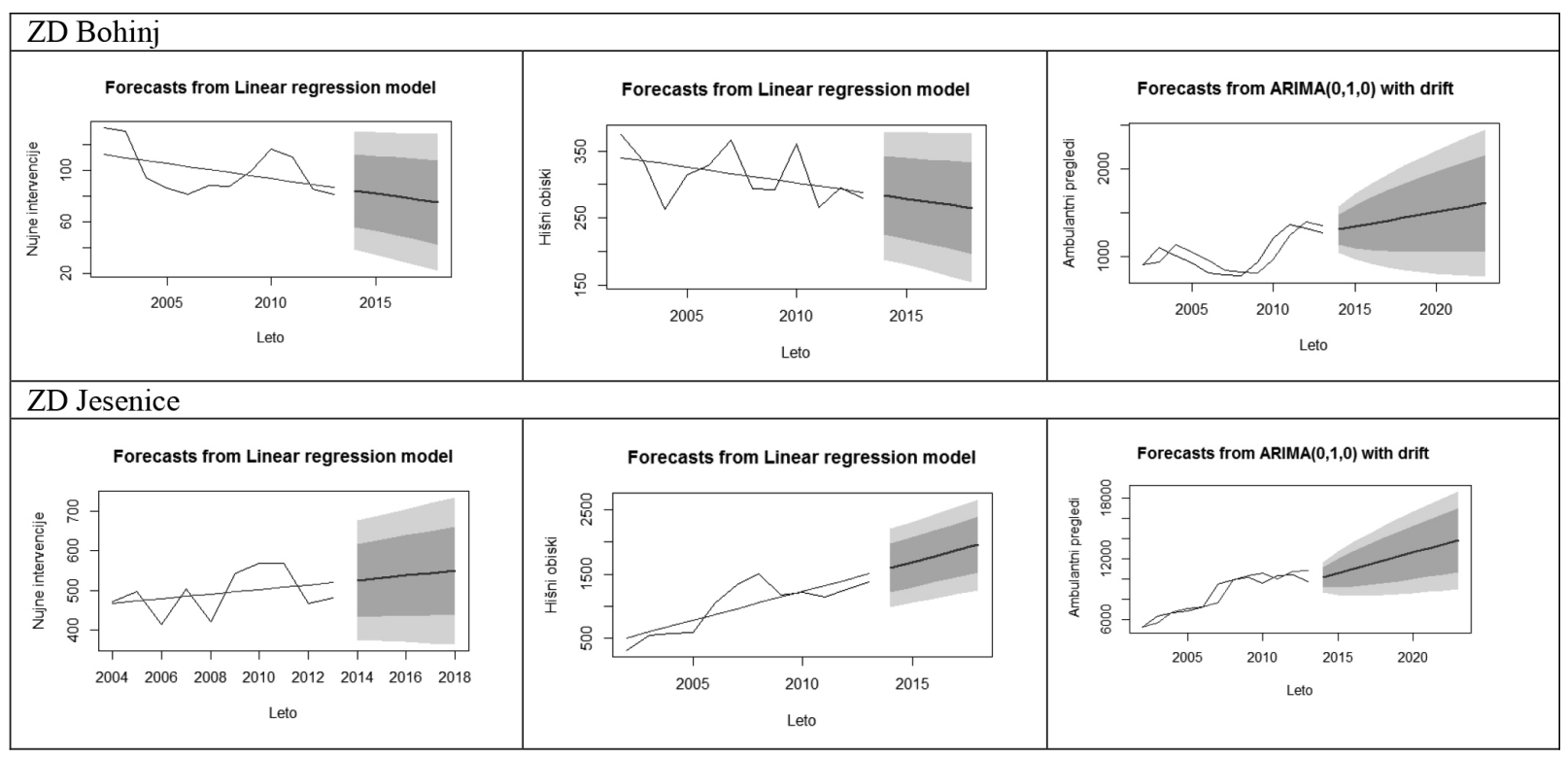

Figure 1: A graphical display of a forecast trend for a number of EMS treatments in the Gorenjska region. (continued)

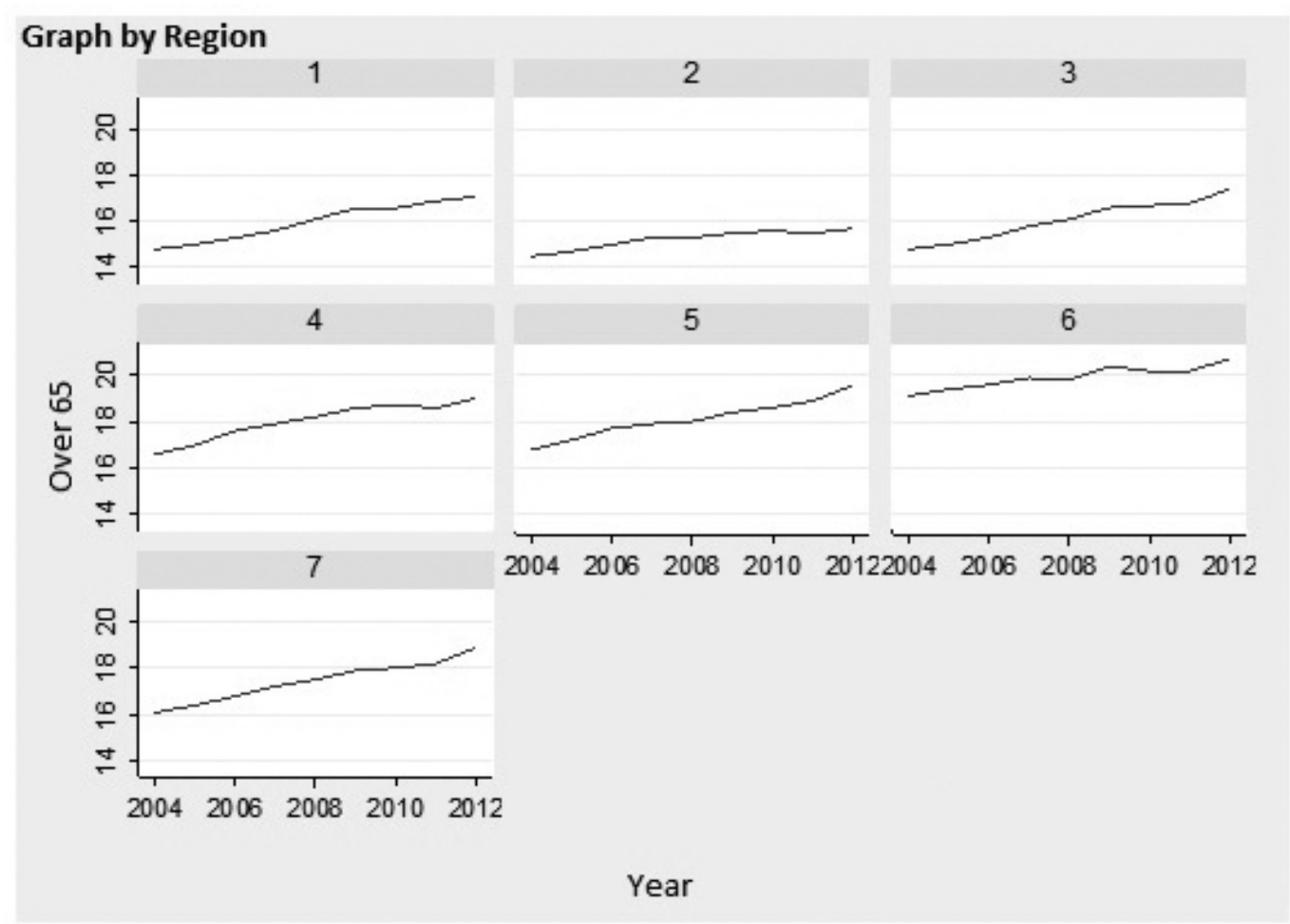

Figure 2: Graphical representations of rising proportions of elderly populations in the Gorenjska region (significance of numbers in the title graphic: 1 - ZD Kranj, 2 - ZD Škofja Loka, 3 - ZD Tržič, 4 - ZD Radovljica, 5 - ZD Bled, 6 - ZD Bohinj, 7 - ZD Jesenice) 
Table 3: Display of proportion of individual EMS treatments performed by OE in Gorenjska, 2008 to 2013 inclusive (hi-quadrant $=9547.928 ; p<0.001$ )

\begin{tabular}{|c|c|c|c|}
\hline Organizational Unit & No. of Emergency Interventions (\%) & $\begin{array}{c}\text { No. of Home Visits } \\
(\%)\end{array}$ & No. of Outpatient Examinations (\%) \\
\hline ZD Kranj & $6736(4.1)$ & $8623(5.2)$ & $150169(90.7)$ \\
\hline ZD Škofja Loka & $3086(4.4)$ & $2589(3.7)$ & $64779(91.9)$ \\
\hline ZD Tržič & $1814(5.1)$ & $2274(6.3)$ & $31728(88.6)$ \\
\hline ZD Radovljica & $1757(4.4)$ & $4693(11.6)$ & $33858(84.0)$ \\
\hline ZD Bled & $3309(9.7)$ & $1729(5.1)$ & $29143(85.3)$ \\
\hline ZD Bohinj & $578(6.2)$ & $1786(19.3)$ & $6891(74.5)$ \\
\hline ZD Jesenice & $3049(4.3)$ & $7674(10.8)$ & $60218(84.9)$ \\
\hline
\end{tabular}

EMS provision) - the variable that we wish to control. The share of explained variance (coefficient of determination) measures over 90 percent in EMS provision in all cases.

The statistically significant $t$ test indicated that the proportion of the population aged 65 and over impacts upon the number of home visits. Even binary variables for regions have a statistically significant impact on the clarification of dependent variables, while the F statistic indicates that the model fits the data well $(\mathrm{F}(9.71)=179.93$; $\mathrm{p}=0.000)$. The proportion of explained variance of the dependent variable which may be attributed to the variation of the independent variable is, at 95.8 percent, very high.

\section{Discussion}

Organizations today work in an extremely dynamic and rapidly changing environment. It is for this reason that they must constantly be aware of and focused on changes in their external environment, all the while monitoring their own internal capacities (Jeffs, 2008, pg. 16). As a result, the external environment and time may reliably be defined as two key factors in the successful operations of all organizations, irrespective of their field of activity (Morden, 2007, pg. 109; Jeffs, 2008, pg. 17).

This research confirms what researchers from other parts of the world have already reported - namely, that the number of EMS treatments is on the rise, as is the complexity of administered treatments (Fischer et al., 2000; Cabrera et al., 2011; Močnik, 2012, pg. 1; Verdel, 2015, pg. 12). The number of EMS treatments is also growing in the Gorenjska region and this trend is expected to continue in the following 5-year period. This fact applies not only to rare exceptions among observed organizational units in Gorenjska, but is common in municipalities throughout the region.

Highly unfavourable demographic statistics are prevalent in the municipalities of Kranjska Gora, Bohinj and Bled, as these areas exhibit the highest ageing index in the region (the ageing index indicates the number of people aged 65 and over, per 100 inhabitants under the age of 15). This study has confirmed that the number of home visits is higher in those municipalities. The case of OE ZD Bled has indicated that a larger proportion of treatments is represented by outpatient examinations, although it is possible to attribute this to the fact that Bled is an extremely well developed tourist destination and the number of outpatient examinations strongly correlates with the development of its tourism activities. In their research, Matter-Walstra and colleagues (2006) have proven a higher number of medical cases during the winter season, a factor that was correlated with a higher number of tourist visits at this time.

This study has several limitations. Firstly, the study covered a relatively short period of time. Secondly, it has become apparent that the data acquired from different research participants was obtained in a somewhat varied manner, which could result in there being some deviation from the benchmark in future research. It has been determined that complete insight into the number of EMS treatments conducted were not held by some of the providers themselves. This reinforces our conclusion that most healthcare organizations in the region unfortunately have little awareness of their efficiency and effectiveness, a fact that has also been reported by foreign researchers. Bryson, for example, notes that a vast majority of public and non-profit organizations are familiar with an entire host of information with respect to financial flows, but few have information on a clear philosophy, core values, research competencies and organizational culture (Bryson, 2004, pg. 40).

\section{Conclusion}

One of the key elements of the modern healthcare system is an efficient and carefully constructed system of prehospital EMS that takes into account social changes. The challenge of modern times is how to maintain the standard and accessibility of healthcare services at their existing level. Many calls for the reorganization of the health care sys- 
tem have been made among the public in recent years. For example, in Slovenia, there has even recently been an extremely controversial establishment of a network of emergency centres aimed at merging EMS prehospitals and hospital emergency divisions. One of the goals in establishing a network of emergency centres that will at some point be reliably positioned in all regions of the country is to improve the quality and efficiency of emergency healthcare conditions.

The undertaken analysis is part of more extensive research that aims to develop a proposal for the formation of an EMS organizational model that will enable the efficient use of human and other resources and which will also realize the provision of efficient and effective medical care, from the perspective of the medical field, health care providers and patients. Some important elements that are critical to consider in the formation of EMS at the prehospital level have been identified. This has shown to anticipate the trend in the number and types of EMS treatments in the Gorenjska region.

In accordance with the findings of this research, the following recommendations for the process of reorganizing EMS activities in the Gorenjska region are proposed. First, due to the continued provision of 24 hour health care service, the merger of some geographically proximate health care providers is recommended. It would be rational to combine units in terms of total coverage of outpatient examinations and in carrying out home visits, taking also into consideration the establishment of emergency centres. Due to assuring good response from EMS teams, it is at present necessary to retain the current allocation of units carrying out paramedic emergency services, although staff profiles may be adjusted in some areas and for some types of services. Prior to any type of reorganization, we must assure the introduction of a dispatch system and triage system, which has not yet been guaranteed for the Gorenjska region.

National policy and Health Ministries face the difficult and important task of determining a formula according to which it will be possible to preserve current access to healthcare services. The public and local communities have a responsibility to understand the reasons for changes in healthcare and to prepare to cooperate in the process of implementing necessary emergency reforms. Finally, managers of healthcare organizations face several challenges, one of which is the reliable development and implementation of a system of monitoring quality, as well as a more efficient response to all changes in the external environment. Strategic planning, the basis of which is to study an organization's surrounding environment, must become a central component in the management of healthcare organizations. This is especially true because organizations do not impact on their external environment.

\section{Acknowledgements}

The authors are extremely grateful to Ms. Jana Suklan for her assistance in the statistical analysis. We are also very grateful to Ms. Mojca Kodric for her assistance in the Slovenian-English translation.

\section{Literature}

Berwick, D.M., Nolan, TW., \& Whittington, J. (2008). The triple aim: Care, health, and cost. Health Affairs, 27(3), 759-769, http://dx.doi.org/10.1377/hlthaff.27.3.759

Bleicher, K. (2011). Das Konzept Integriertes Management. Frankfurt am Main: Campus Verlag.

Bryson, B. (2004). Strategic Planning for Public and Nonprofit Organizations. San Francisco: Jossey-Bass.

Bufon, M. (2014). Družbena geografija sveta: Globalni sistemi in regionalne dinamike [Social geography of the world: The global systems and regional dynamics]. Koper: Univerzitetna založba Annales. Retrieved June, 23, 2015 from http://www.zrs.upr.si

Cabrera, E., Taboada, M., Iglesias, M.L., Epelde, F., \& Luque, E. (2011). Optimization of healthcare emergency departments by agent-based simulation. Procedia Computer Science, Vol. 4, 1880-1889, http://dx.doi. org/10.1016/j.procs.2011.04.204

Caley, M., \& Sidhu, K. (2010). Estimating the future healthcare costs of an aging population in the UK: expansion of morbidity and the need for preventative care. Journal of Public Health, 33(1), 117-122, http:// dx.doi.org/10.1093/pubmed/fdq044

Capon, C. (2008). Understanding Strategic Management. Harlow: Prentice Hall.

Daft, LR. (2010). New Era of Management. South-Western, Cengage Learning.

Fischer, A.J., O'Halloran, P., Littlejohns, P., Kennedy, A., \& Butson, G. (2000). Ambulance Economics. Journal of Public Health Medicine, 22(3), 413-421, http://dx. doi.org/10.1093/pubmed/22.3.413

Hedegaard, J., \& Ahl, H. (2013). The gender subtext of new public management-based work practices in Swedish health care. Equality, Diversity and Inclusion: An International Journal, 32(2), 144-156, http:// dx.doi.org/10.1108/02610151311324389

Hitt, M.A., Black, J.S., \& Porter, LW. (2009). Management. Upper Saddle River, NJ: Prentice-Hall.

Horibata, K., \& Takemura, Y. (2015). Inappropriate use of ambulance services by elderly patients with less urgent medical needs. The Tohoku Journal of Experimental Medicine, 235(2), 89-95, http://doi.org/10.1620/ tjem.235.89

Hyndman, RJ. (2015). Forecasting functions for time series and linear models. Retrieved October 1, 2015 from http://cran.r-project.org/web/packages/forecast/ forecast.pdf

Jeffs, C.(2008). Strategic management.London: SAGEPub- 
lications, $\underline{\text { http://dx.doi.org/10.4135/9781446216446 }}$

Kohler, U., \& Kreuter, F. (2009). Data Analysis Using Stata. Stata Press, Texas.

Kowalczyk, R. (2002). The effect of new public management on intensive care unit staff. The International Journal of Public Sector Management, 15(2), 118-128, http://dx.doi.org/10.1108/09513550210419573

Kuhlmann, E., \& von Knorring, M. (2014). Management and medicine: Why we need a new approach to the relationship. Journal of Health Services Resesarch and Policy, 19(3), 189-191, http://dx.doi. org/10.1177/1355819614524946

Lünger, B., \& Luhan, M. (2010). Strategische Krankenhausmanagement in der Praxis. V: Debatim, J.F., Ekkernkamp, A., \& Schulte, B. (Hrsg.) (2010). Krankenhausmanagement. Berlin: Medizinisch Wissenschaftliche Verlagsgesellschaft.

Matter-Walstra, K., Widmer, M., \& Busato, A. (2006). Seasonal variation in orthopedic health services utilization in Switzerland: The impact of winter sport tourism. BMC Health Services Research, 6: 25, http:// dx.doi.org/10.1186/1472-6963-6-25

Ministry of Health. (2013). Javna mreža primarne zdravstvene dejavnosti $v$ republiki Sloveniji [The public network of primary healthcare activities in the Republic of Slovenia]. Retrieved June 2, 2015 from www.mz.gov. $\underline{\text { si }}$

Morden, T. (2007). Principles of Strategic Management. Ashgate Publishing Limited, Hampshire.

Močnik, U. (2012). Analiza čakalnih vrst v dežurni ambulanti zdravstvenega doma [Analysis of emergency department waiting lines in Community Health Centre]. Master's Thesis, Ljubljana: Faculty of Economics.

Müller, A.W., \& Müller-Stewens, G. (2009). Strategic Foresight. Stuttgart: Schäffer-Poeschel Verlag.

Pravilnik o službi nujne medicinske pomoči [Rules on emergency medical services].Pravilnik o službi nujne medicinske pomoči (Uradni list RS, št. 106/08 z dne 11. 11. 2008), Official Gazette RS, no. 106/2008.

Ramani, K.V., Mavalankar, D., \& Govil, D. (2008). Strategic Issues and Challenges in Health Management. New Delhi: SAGE Publications.

Robbins, SP., \& Coulter, M. (2009). Management. Upper Saddle River, NJ: Prentice-Hall.

Rodriguez-Garcia, R. (2001). The health-development link: Travel as a public health issue. Journal of Community Health, 26(2), 93-112, http://dx.doi. org/10.1023/A:1005225129295
Rodríguez Perera, FP. \& Peiró, M. (2012). Strategic Planning in Healthcare Organizations. Rev Esp Cardiol, 65(8), 749-754, http://dx.doi.org/10.1016/j. rec.2012.04.004

Salvi, F., Morichi, V., Grilli, A., Giorgi, R., De Tommaso, G., \& Dessi-Fulgheri, P. (2007). The Elderly in the Emergency Department: A Critical Review of Problems and Solutions. Internal and Emergency Medicine, 2(4), 292-301, http://dx.doi.org/10.1007/s11739-0070081-3

Šelb-Šemerl, J., Rok-Simon, M., Kelšin, N., \& Ivas, N. (2004). Staranje prebivalstva v Sloveniji: demografske spremembe in nekaj posledic za zdravstveno varstvo. Posvet slovenskega zdravniškega društva o problematiki starostnikov in staranja [The Ageing of the Population in Slovenia: Demographic changes and some consequences for Healthcare. Consult of the Slovenian Medical Association on the problems of older people and aging]. Retrieved June 3, 2015 from www.szd.si

Varkey, P., \& Bennet, KE. (2010). Practical Techniques for Strategic Planning in Health Care Organizations. Physician Executive Journal, 36(2), 46-48.

Verdel, D. (2015). Obravnava nenujnega pacienta vambulanti nujne medicinske pomoči [Treatment of non-urgent patient in the emergency department]. Master's Thesis, Maribor: Faculty of Health Sciences.

Walshe, K., \& Smith, J. (2011). Healthcare Management. Berkshire: Open University Press.

Wo, C.H., \& Hwang, P.K. Using a discrete-event simulation to balance ambulance availability and demand in static deployment systems. Academic Emergency Medicine, 16(12), 1359-1366, http://dx.doi.org/10.1111/ $\mathrm{j} 1553-2712.2009 .00583 . \mathrm{x}$

Tatjana Kitić Jaklič attained her specialization in Family Medicine at the University of Ljubljana. She practices as a family medicine doctor at the Kranj Community Health Centre, Division for General Medical Practice Activities of the Gorenjska Region. Her current research interests encompass organizational methods and techniques for achieving greater efficiency and effectiveness in the field of healthcare.

Jure Kovač is a Professor of Organization and Management at Faculty of Organizational Sciences, University of Maribor. His research interests are organization theory, organization design and management development. 